\title{
Selection criteria of Pediococcus sp. and Bifidobacterium bifidum Strains Isolated from Cereals Based on Fermented Food for Probiotic use ${ }^{\dagger}$
}

\author{
Devika D. ${ }^{1}$, Aswani K.S. ${ }^{1}$, Shylanath G. ${ }^{1}$, S. Dhiva ${ }^{1, *}$ \\ 1 Department of Microbiology, Sree Narayana College, Alathur, Palakkad Dist, Kerala, India \\ * Correspondence: dhivasoju@gmail.com; \\ $\dagger$ Presented at International e-Conference on Bioengineering for Health and Environment (ICBHE 2020)
}

Received: 5.07.2020; Revised: 10.07.2020; Accepted: 12.07.2020; Published: 15.07.2020

\begin{abstract}
Cereal based Fermented foods are a rich source of Probiotic organisms. Once if the Probiotic organisms are consumed, it should be capable of adhering to the colon region. To find out the efficiency of Pediococcus sp. and Bifidobacterium sp. they were subjected to in-vitro tests such as tolerance to bile, resistance to low $\mathrm{pH}$ values, cell adhesion and antagonistic activity among the two organisms, Bifidobacterium sp. showed better growth at $\mathrm{pH} 3.5$ than Pediococcus sp. during the increased incubation time. Cells remain viable up to $0.8 \%$ of bile concentration beyond which the multiplication was slow in the case of both the strains. Bifidobacterium sp. showed good adherence to the substratum than Pediococcus sp. Both the organisms were antagonistic against common enteric pathogens, which is an ideal characteristic of a probiotic.
\end{abstract}

Keywords: Probiotic; acid and bile tolerance; cell adhesion; hemolysis; antagonism.

(C) 2020 by the authors. This article is an open-access article distributed under the terms and conditions of the Creative Commons Attribution (CC BY) license (https://creativecommons.org/licenses/by/4.0/).

\section{Funding}

This research received no external funding.

\section{Acknowledgments}

This research has no acknowledgment.

\section{Conflicts of Interest}

The authors declare no conflict of interest. 